\title{
Cultural Landscapes in Asian Modernity
}

\author{
Kenneth Wong See Huat \\ Penang Institute, Malaysia
}

Copyright $(2015$ by authors, all rights reserved. Authors agree that this article remains permanently open access under the terms of the Creative Commons Attribution License 4.0 International License

\begin{abstract}
This study is to investigate the relationship between the cultural landscapes in Asia and Asian Modernity. As first variable, the cultural landscapes chosen are from the UNESCO World Heritage Listing, up to the year 2012. Modernity, the second variable, is the result of simultaneous and contradictory influences and consequences of homogenization, pluralization, and hybridization of the material and non-material items. The foundation of this study is established by studying the basic information of Asian countries, where the cultural landscapes are situated, its population and density, ethnic majority, governance system, and the nomination criteria of UNESCO. The sites are then linked to the contemporary backdrop to reveal the great diversity of the interactions between humans and their environment over the time span, to see whether they are sustaining the traditional living cultures, and to see how the current politics, socio and economic circumstances influence the sites. The analysis is based on four categories: (i) Early human settlement and spirituality (Grottos and sacred sites), (ii) Economy and cultural activity prove (plantation, mining and trading route), (iii) Ancient township and empire remains, and (iv) Intentional human intervention landscape. Out of the 17 cultural landscapes in Asia, 16 are considered highly relevant with its modernity. The cultural landscapes do contribute to ethnic or cultural identity affirmation and pride in Asia, in the probe of modernity. The analysis also prompts us to think further whether the result would be different if other continent (other than Asia) would have been adopted. The positive result indicates the urge for the relevant institutions to brainstorm on what could be done to further enhance the cultural landscapes in this modern era. The proven relationship brings out the significance in safeguarding the continuity of cultural landscape's essence amidst flow of modernity.
\end{abstract}

Keywords Asian Modernity, Cultural Landscape, UNESCO, Essence, Continuity

\section{Introduction}

Cultural landscapes had been well defined and well discussed since the introduction of this new terminology by UNESCO in year 2005. Lots of research had carried out to further develop the management plan of the nominated or the potential cultural landscapes, especially in Asia, which deemed less informed compared to Europe. On the other hand, there are general discussions about "modernity and Asia", and modernity is always counter-posed to tradition. This paper is not to examine the circulation of the ideology that "modern west is superior to traditional east", but simply link up the two variables, cultural landscape and Asia modernity. The aim is to assess the value of cultural landscapes in Asia to the contemporary society to date, or in fact the influence is another way round, or both coexist independently without much of synergy.

\section{Literature Review}

The World Heritage Committee has identified and adopted three categories of cultural landscape, ranging from what had extracted from the Committee's Operational Guidelines, are as follows (UNESCO [1]):

(i)"a landscape designed and created intentionally by man";

(ii) An "organically evolved landscape" which may be a "relict (or fossil) landscape" or a "continuing landscape";

(iii) An "associative cultural landscape" which may be valued because of the "religious, artistic or cultural associations of the natural element"

Although cultural landscape studies traditionally have focused on the dispersion of human features within areas to comprehend processes affecting landscapes and culture, the gaze of cultural landscape studies has expanded to include investigating the wider political, social, and economic structures in societies that initially produced these features. Cultural landscape studies, as a result, have begun to question the meanings embedded within these features and to view the landscape as a social expression of symbols, icons, and metaphors (McDowell [2]).

The Heinrich Böll Foundation [3] holds that culture is, more or less, always dynamic and constantly adapts to changing societal, political, economic, and ecological 
conditions. According to Wischermann [4], to emphasize on multiple modernity is to realize and recognize the peculiarity of modernity of different civilizations and different regions, in the world "In this new world society or global society, there are always simultaneous and contradictory influences and consequences of homogenization, pluralisation, traditionalization, and hybridization of the components of culture - material (food, clothing, leisure, etc.) and non-material/symbolic items (value system, institutions, etc.)".

Ten [5] holds that modernity is built on the basis of being secular. This has been borne out by Europe's historical experience and it is being reaffirmed by some other nonEuropean countries. In the course of modernization, Asian countries will tap into their own cultural and intellectual heritage and develop new ideas, morality, culture and institution based on it. The sustainability of Cultural Landscapes in Asia will always have its reflection on what is going on in the current political, social and economic climate. Secularism has its universal applicability, but it also has culturally specific expression, in Asian Modernity.

Besides, Michael H. [6] affirmed that, the past provides us with psychological comfort and anchorage, cultural, and intellectual reassurance and a sense of identity. That is why people find it so hard to come to terms with those aspects of their history which are blatantly evil; why nation-building projects draw on the glorious chapters of their own history; why debaters like to draw on historical instances to illustrate and buttress a point; and why novelists and poets like to rework real or imagined events. Therein Michael H. agreed to philosopher Hans-Georg Gadamer [6] that, the real force of morals is based on tradition. But at the same time, we must not forget that tradition encompasses many, and sometimes incompatible ideas and beliefs, rituals and practices.

Herein, the mentioned readings hints that it is important to safeguard the continuity of cultural landscape's essence in facing the abrupt threat of political change, globalization and urbanization which have brought increasing mobility, accelerated ongoing change of lifestyle, etc.

\section{Methodology}

This study is a conceptual research. The approach is qualitative. It involves library research and desktop analysis only and there is no fieldwork being carried out on site. The scope is mainly focused on the established 17 cultural landscapes (in Asia only) that have been recognized as world heritage by UNESCO until July 2011. Among them, the sites are being categorized by the author into (i) Early Human Settlement and Spirituality (Grottos and Sacred Sites), (ii) Economy Activity Prove and Cultural (Plantation, Mining and Trade Route), (iii) Ancient Township and Empire Remains, and (iv) Intentional Human Intervention Landscape. By then, each sub categories are being analyzed according to its general info of country the site located, its success justification for the nomination, and its relevance to the modern context. The sites are linked to the contemporary backdrop to reveal the great diversity of the interactions between humans and their environment over the time span, to see whether they are sustaining the traditional living cultures, and to see how the current politics, socio and economic circumstances influence the sites. Discussion avoids the integrity and authenticity issue of the sites as deemed redundant, compared to the existing UNESCO documentation.

\section{Finding and Analysis}

Up to 2012, sixty six (66) properties on the World Heritage List [7] have been included as cultural landscapes. Among those, seventeen (17) sites are found in Asia. In general, they are considered as archaeology remains and architecture representation. Herein, the sites are categorized according to the same function and characteristic of the cultural landscape sites.

\subsection{Early Human Settlement and Spirituality (Grottos)}

The dense and coherent group of petroglyphs, with sacred images, altars and cult areas, together with their associated settlements and burial sites, provide a substantial testimony to the lives and beliefs of pastoral peoples of the central Asian steppes from the Bronze Age to the present day [7].

At the very same site of Archaeological Landscape of Tamgaly (Kazakhstan, Figure 1), the action of Kazakh Muslims tied the rags at the bush synchronizes with the ancient action of petroglyphs (Figure 2), as the ritual dedication for this holy site pilgrimage. According to Kenneth Lymer [8], the rags at Tamgaly (Figure 3) do not merely mark sites special to Kazakh Muslims, but are the personal dedications of the pilgrims to the ancestors and saints of a place, which are deeply embedded in a nexus of relationships related to how a local community conceives and interacts with the tangible and intangible worlds around it.

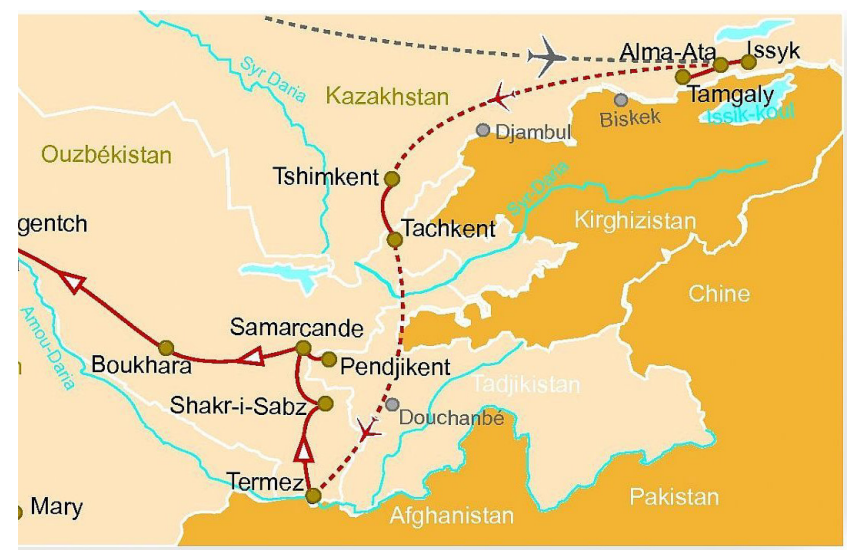

(Source: http://www.worldpixs.com/601265-Tamgaly)

Figure 1. Tamgaly in Kazakhstan 


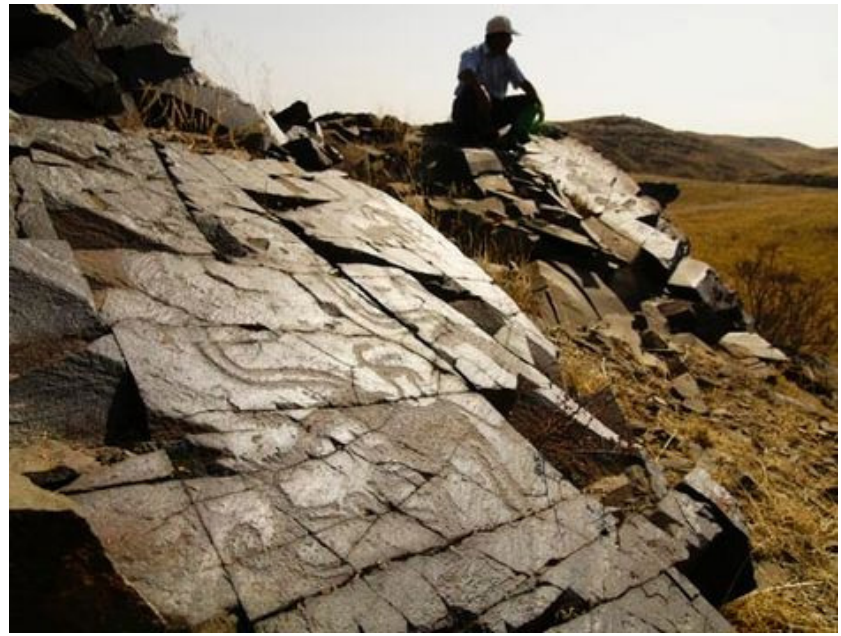

(Source: OUR PLACE The World Heritage Collection)

Figure 2. Petroglyphs with sacred images

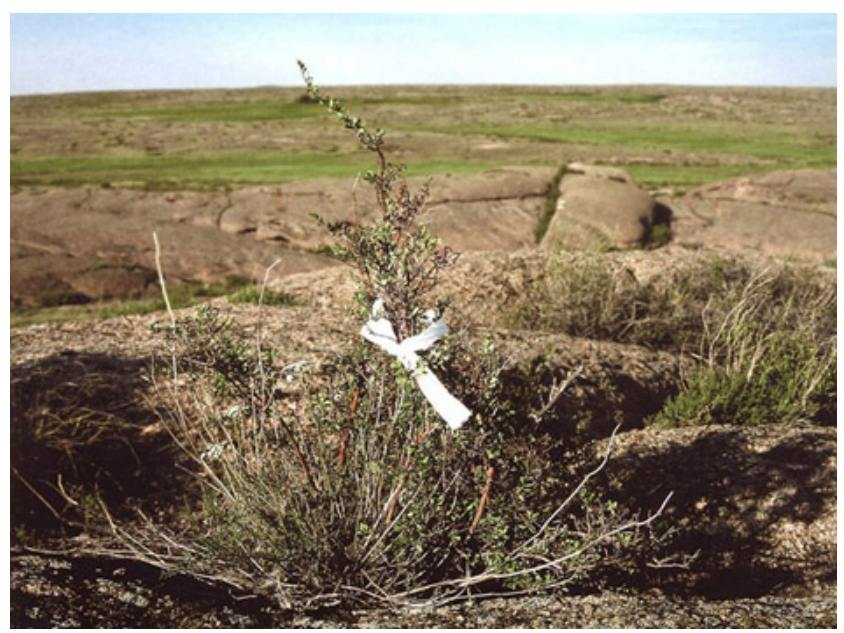

(Source: http://www.basr.ac.uk/diskus/diskus11/lymer.html)

Figure 3. Rag bush with the vast steppe in the background

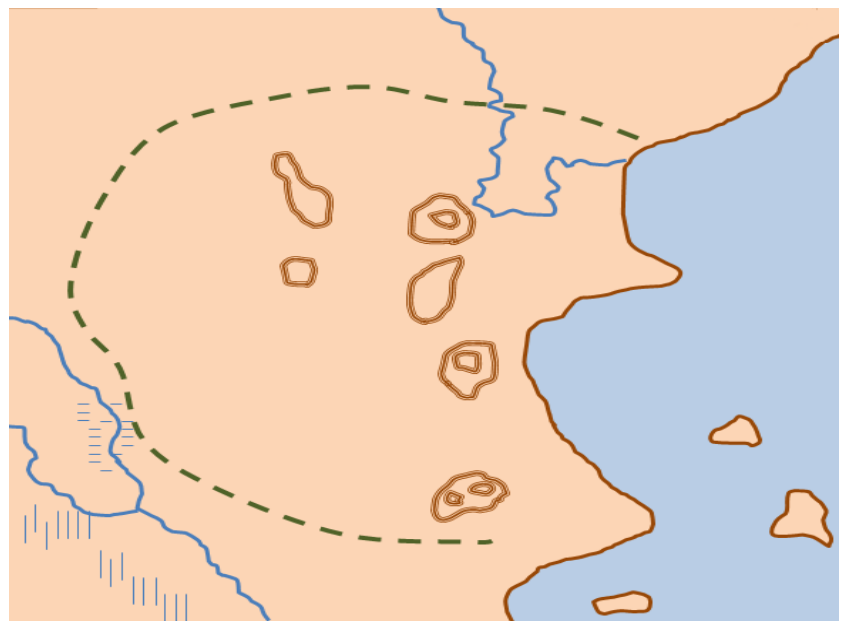

(Source: http://commons.wikimedia.org/wiki)

Figure 4. Gobustan State Reserve in Azerbaijan

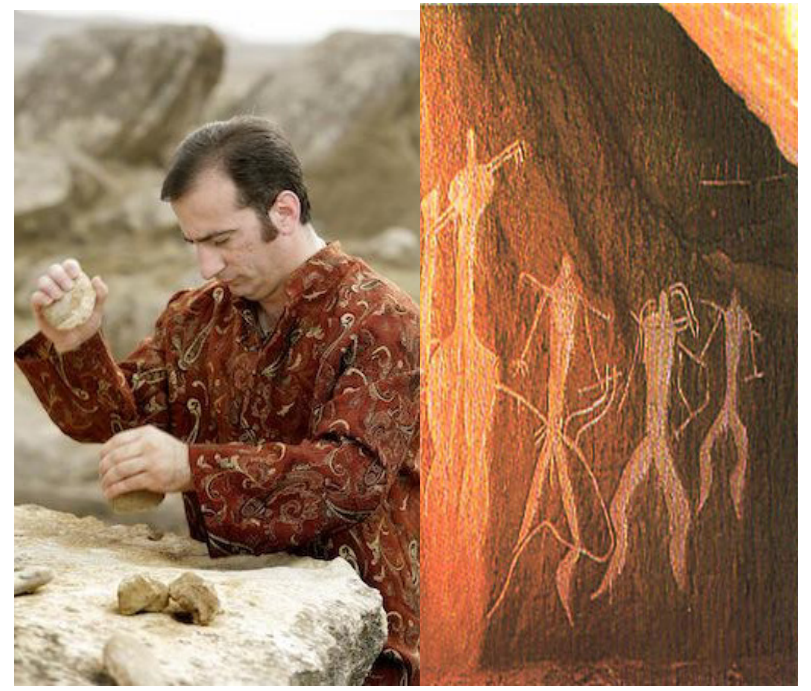

(Source: http://www.royaltravels-az.com/en/index.php?link=03_azerb; http://www.myspace.com/natigshirinov/photos/69492)

Figure5. Rock Painting of Gobustan (Left); Performance on the Gaval Dash, natural musical stone (Right),

Azerbaijan is among the areas of earliest human settlement, with evidence of human habitation since the Palaeolithic age. Settlements engaging in agriculture and livestock-raising were widely distributed in this area in the seventh and sixth millennia BC. Rock paintings in Gobustan (Figure 4) are dated by scholars to the XIII millennia BC. However, there is no direct proof of relationship between the Gobustan Rock Art Cultural Landscape with the famous oil resource of Azerbajian. Yet, there is the musical gemstone (Figure 5) known as Gaval Dash that only origin from the rock art preserve area that make a tambourine-like sound to continue its soul.

For Rock Shelter Bhimbetka (India), the current lifestyles of the India Adivasi (indigenous) settlements i.e.Gonds, Pradhans and the Korkus peoples in the area still show the strong affinity of rock painting, through the wall painting traditions on houses (Figure 6). Similar decorative elements are found on pots and other handcrafted items of everyday use. These people also still use the resources of the forest at certain times of year for hunting and for gathering edible produce - as illustrated in the cave paintings (Figure7). However, the poverty of these innocent tribal has forced to abandon their tribal values and take to vulgar commerce: from walls and floor, the Adivasi has gradually switched to paper and canvas to cater to the market for decorative art.

The Petroglyphic Complexes of the Mongolian Altai Mountain provide an exceptional documentation of the pre-historic and early historic communities in the northwestern Altai Mountains. Even though local inhabitant Herders have been engaged in heritage protection in some soum (departments), the livestock breeding and the seasonal migration of the nomad households are no longer organized 
by the government. To avoid transportation costs, two thirds of the families have reduced their seasonal migrations (Lkhagvadorj D., Hauck M., Dulamsuren C., and Tsogtbaata J., n.d. [9]). This trend was favored also by rising temperatures and earlier snowmelt during the last few decades, resulted in a shortage of fodder and intensified forest use.

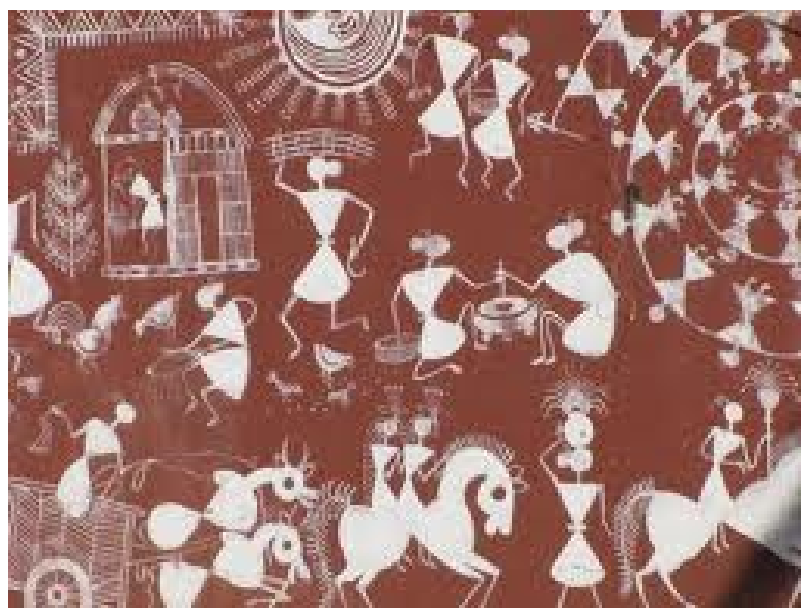

(Source:

http://article.wn.com/view/2011/02/21/In_pictures_Ancient_Warli_art_flo urishes_in_rural_India/)

Figure 6. The tribe painted walls to mark important occasions such as weddings and the rice harvest.

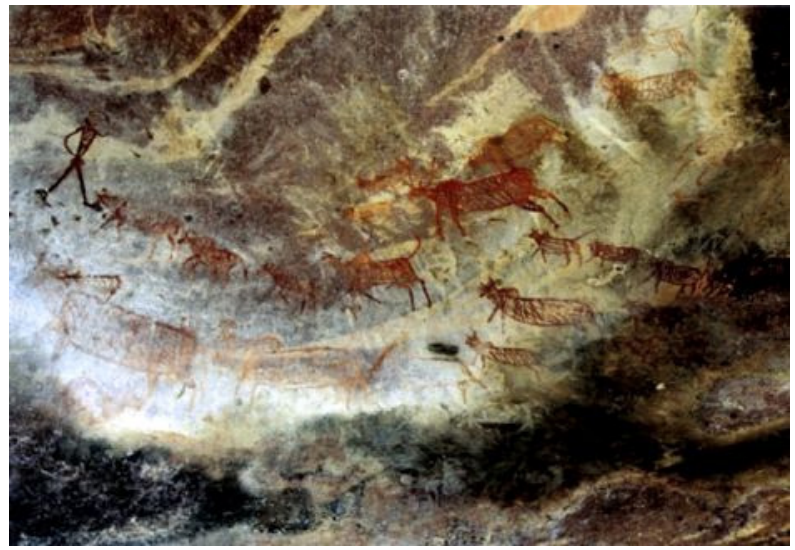

(Source: http://whc.unesco.org/en/list/925)

Figure 7. The prehistoric rock shelters and paintings at Bhimbetka

\subsubsection{Sacred Sites}

Nearly every culture in human history has sought to honor the divine, the mysterious, the supernatural, or the extraordinary in some way. Most often this happens at sacred sites - special places where the physical world seems to meet the spiritual world. Sacred sites remain spiritually meaningful to millions today and the ancient practice of pilgrimage is as popular as ever.

The artistic and architectural remains of Bamiyan Valley, an important Buddhist centre on the Silk Road, are an exceptional testimony to the interchange of Indian, Hellenistic, Roman and Sasanian influences as the basis for the development of a particular artistic expression in the Gandharan School. For Cultural Landscape and
Archaeological Remains of the Bamiyan Valley (Figure 8), it manifests the political reform when the Taliban in Afghanistan potentially threatens the status of asset regardless the significance of its most monumental expression of the western Buddhism.

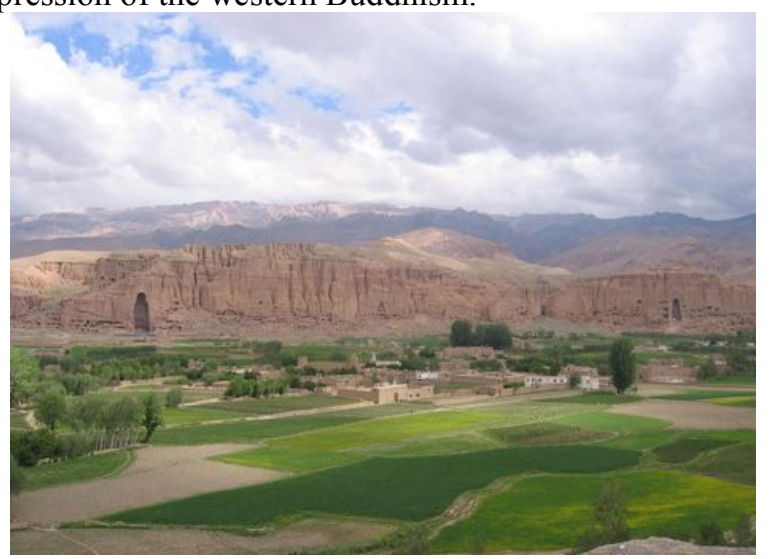

(Source: http://whc.unesco.org/en/list/208/gallery/)

Figure 8. General view of the Bamiyan Valley

The destruction of the Bamyan Buddhas became a symbol of oppression and a rallying point for the freedom of religious expression. Although most Afghans are now Muslims, they too had embraced their links to the past and a number were appalled by the destruction in 2001.

For Lushan National Park, its outstanding aesthetic value and its powerful associations with Chinese spiritual and cultural life, is adorned and popularized by writers, scholars and poets since ancient times (Figure 9). Other great religions, such as Islam and Christianity, also established centres at Lushan. Its spiritual and political significance has endured to the present day. During the 1930s and 1940s, it was the official summer capital for the Republic of China. With the establishment of the People's Republic in 1949, it was the venue for meetings of the Central Committee of the Chinese Communist Party under the chairmanship of Mao Tzedong [Advisory Board Evaluation, 10]. The closing years of the 19th century and the early 20th century, Lushan become a fashionable holiday area, and many villas were built by Chinese and foreign visitors.

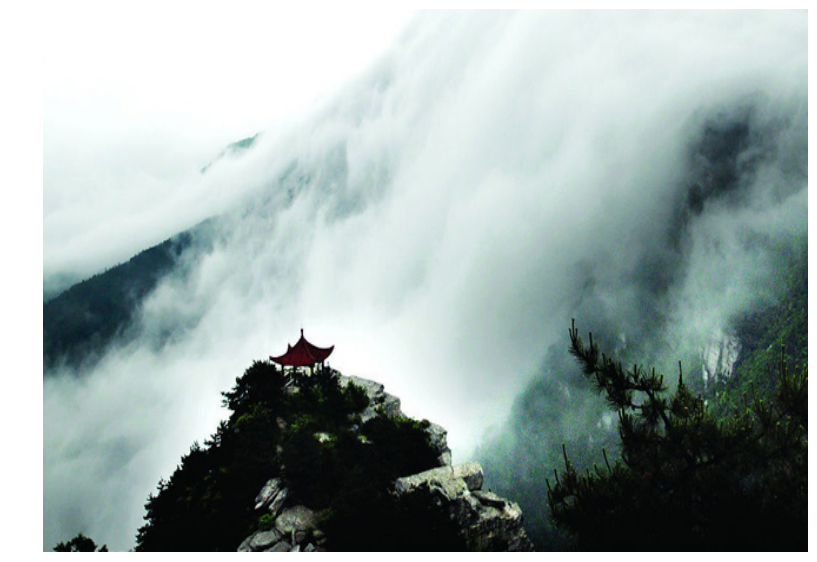

(Source:

http://www.absolutechinatours.com/Nanchang-attractions/Lushan-Mountai n-A-World-Heritage-in-China-3418.html)

Figure 9. Pavilion and Xiefeng Peak among Sea of Clouds 
The sacred mountain Wutai is believed to be the earthly abode of the Bodhisattva of Wisdom, Mañjuśrī (Figure 10). From the seventh century on, it attracts Buddhist pilgrims from as far as India, Kashmir, Tibet, Japan, and Korea. Tibetan Buddhism was at its apex there and the mountain was a confluence of Himalayan cultures by eighteen centuries. Buddhism flourished once more in the Ming dynasties. Its revival also showed the social instability from the late Qing dynasty to the early years of the Republic of China, abruptly flourishing as an international pilgrimage Centre. Mount Wutai's political significance has not been lost on modern China's leaders either, as Mao himself stopped at Mount Wutai on his way to Beijing in 1949, it would seem in acknowledgement of the mountain's historic role in the coronation of rulers and the founding of empires (Debreczeny, [11]).

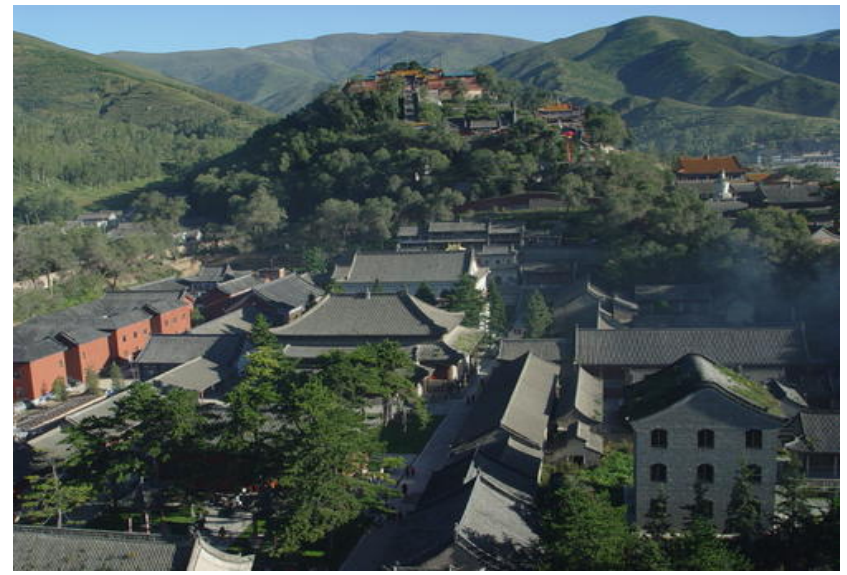

(Source: Liu Hao, http://whc.unesco.org/en/list/1279/gallery/)

Figure 10. Wutai Shan literately in Chinese meant "five-terrace mountain",

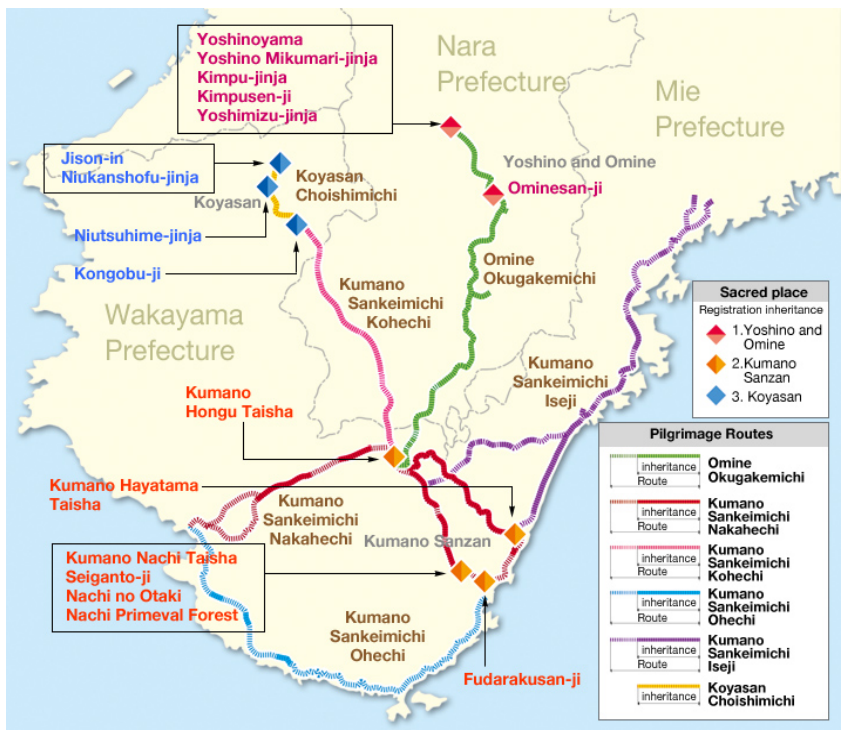

(Source: http://www.koya.org/english/heritage_002.html)

Figure 11. Sacred Sites and Pilgrimage Routes in the Kii Mountain Range

For Sacred Sites and Pilgrimage Routes (Figure 11) in the Kii Mountain Range, the walking boom and wellness concerns create a new perception of the Kumano forest, which spoke of religious beliefs with association that, forest as part of ascetic practice. The forest covering the mountains has been the main economic resource for the region for hundreds of years. Through time, this economic activity has brought tremendous change to the forest and today's visitors have little to do with the pilgrims of the past. The main issues relating to authenticity is the reconstruction of monuments. However, there is a long tradition of reconstructing and renewing the wooden fabric of buildings: the idea, design and location of the building are considered crucial, whereas the individual components may or may not be original (ICOMOS, [12]).

The medieval name of Sulaiman-Too is Bara-Kukh, meaning, in Persian, "a beautiful mountain that stands separately." The current name derives from the legend that the prophet Muhammed once visited the mountain. The legend is repeated in 17th century Arab manuscripts. Historians believe the mountain began functioning as a sanctuary in $1000 \mathrm{BC}$, during the Bronze Age. For Sulaiman-Too Sacred Mountain (Figure 12), the huge Muslim world do recognize the city of Osh as one of the centers of Islam, despite the mobs that went on an arson and looting spree in Krygystan in June 2010, involving ethnic Kyrgyz and Uzbeks in and around Osh and Jalalabad left over 400 people dead. And there it is before us, the ancient city in whose vivid evidence for strong traditions of mountain worship which have spanned several millennia and been absorbed successfully by Islam, is intertwined with a modern tragedy.
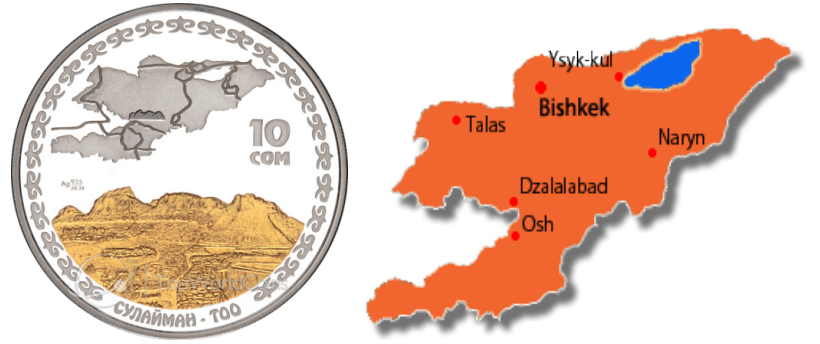

(Source: http://topworldcoins.com/ and http://www.sairamtourism.com/kyrgyzstan_ca)

Figure 12. Sulaiman-Too Sacred Mountain forms the backdrop to the city of Osh.

\subsection{Economy Activity Prove and Cultural (Plantation, Mining and Trade Route)}

\subsubsection{Plantation}

Of all Philippine monuments, the rice terraces are the best known throughout the country. In fact, most Filipinos regard the terraces as their greatest national symbol, a fitting tribute to the traditional thinkers who set the management system centuries ago. The system has been orally handed down to allow their people to continue living on the site and continue growing rice. (Brown J. eds [13]). Rice Terraces of the Philippine Cordilleras have to juggle between traditional and progress, looking at its erosion of architectural qualities by thoughtless replacement of the natural materials with simply rigid concrete, and roof thatch with galvanized iron sheets. 
An example of the culture-nature connection is that the harvesters' ability to stand erect while harvesting and simultaneously chanting the hud-hud (Villaló, n.d. [14])would not have been possible without the waist-high highland variation in the rice strain (Figure 13), which is different from the lowland rice variety that requires bending to harvest the stalks.

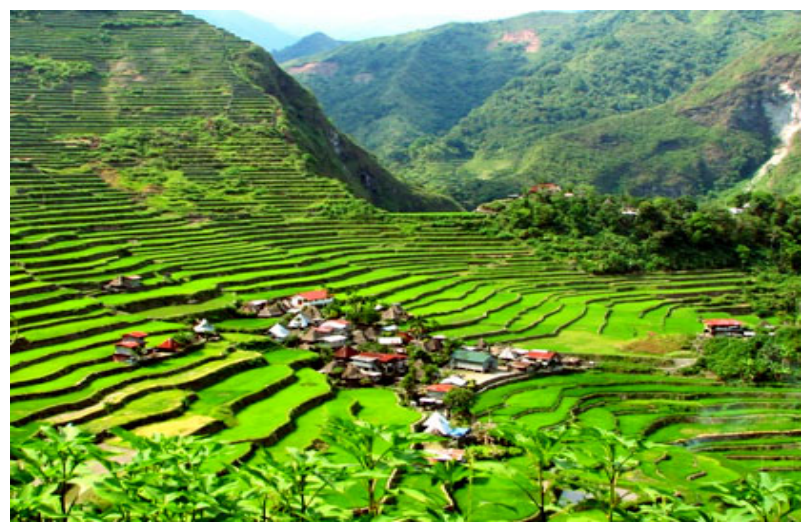

(Source:http://www.destination360.com/asia/philippines/banaue-rice-terrac es)

Figure 13. The Banaue Rice Terraces have often been called the "Eighth Wonder of the World" due to the extend and height of these gigantic stairways.

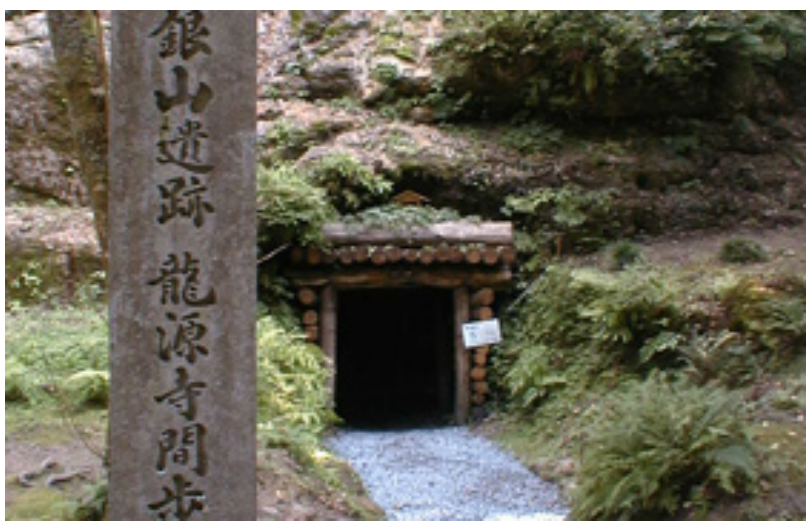

(Source: http://japan-cruise.com/culture/heritage.html)

Figure 14. Iwami Ginzan Silver Mine Ruins are located in the San-in Region facing the Japan Sea

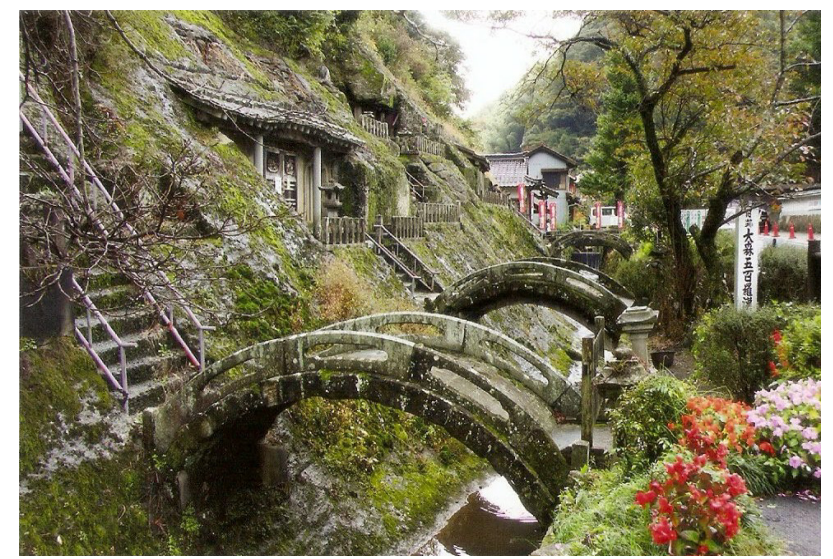

(Source:

http://smspostcard3.blogspot.com/2009/05/missing-japan-iwami-ginzan-sil ver-mine.html)

Figure 15. Gohyakurakan Sori Bridge, The Omori Ginzan Preservation District

\subsubsection{Mining}

The Iwami Ginzan Silver Mine and its Cultural Landscape preserves archaeological remains from the 16th to the 20th centuries and expresses the significance of the mines (Figure 14), their smelting and refining sites, the trade routes through the mountains and the ports (Tomogaura, Okidomari, and Yunotsu) from which the silver ore was shipped (Japanvisitor.com, [15]). The outer town Omori still preserves old townscape, which is a mixture of samurai and merchant houses, administrative buildings, temples, and shrines, while pits in the Ginzan district are open for public appreciation (Figure 15). As one experiences and contemplates contemporary Japan, it quickly becomes clear that concepts such as urban and rural, traditional and modern have abstracted into the realm of ideas people use and manipulate as they create and adapt to their contemporary social milieu (Traphagan J. W. and Thompson C.S. [16]).

\subsubsection{Trade Route}

The Incense trade route comprised a network of major ancient land and sea trading routes linking the Mediterranean world with Eastern and Southern sources of incense, spices and other luxury goods.

Most of the time, the modern and traditional way of life in Israel manage to peacefully co-exist, so for Incense Route Desert Cities in the Negev. It just needed a continuing comprehensive archaeological strategy for the whole. The four Nabatean towns of Haluza, Mamshit, Avdat and Shivta, along with associated fortresses and agricultural landscapes in the Negev Desert, are spread along routes linking them to the Mediterranean end of the incense and spice route (Figure 16). Together they reflect the hugely profitable trade in frankincense and myrrh from south Arabia to the Mediterranean, which flourished from the 3rd century BC until the 2nd century AD (UNESCO [7]). With the vestiges of their sophisticated irrigation systems, urban constructions, forts and caravanserai, the limited development of the region has given the sites considerable protection from development.

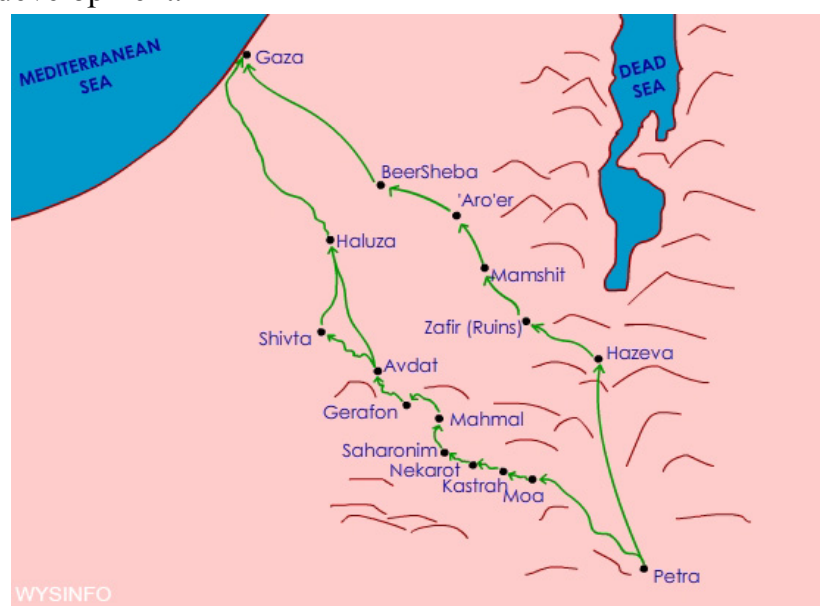

(Source:http://www.wysinfo.com/Perfume/Some_perfume_route_stations. htm)

Figure 16. The Incense route from Petra to the west, through the Israeli Negev to the port of Gaza by the shore of the Mediterranean, stretches across some $150 \mathrm{~km}$. 
As indicated by World Heritage Memory Net, Bam and Its Cultural Landscape(Iran) reached its zenith from the 7th to 11 th centuries, as it sat at the crossroads of significant trade routes and known for its silk and cotton garments production (World Heritage Memory Net [17]). Bam grew in an oasis created owing to an underground irrigation canals (qanats), which has continued its function until today (Figure 17). The proper functioning of the qanats has required a system of strict social coordination for regular maintenance and care. The significance and protection of the area thus be defined on the basis of vital social functions and processes (Jokilehto J., [18]), including those related to management of water resources, farming and agricultural production, trading and production of goods, residential and defence functions. The city of Bam represents an outstanding example of a fortified settlement and citadel in the Central Asian region, based on the use of mud layer technique (Chineh) combined with mud bricks, Khesht (Figure 18).The name of Bam has been associated silk worm, however, the modern Bam residents have engaged mainly in palm cultivation and trade (Dezham Khoov M. \&Yazdi L. P. [19]).

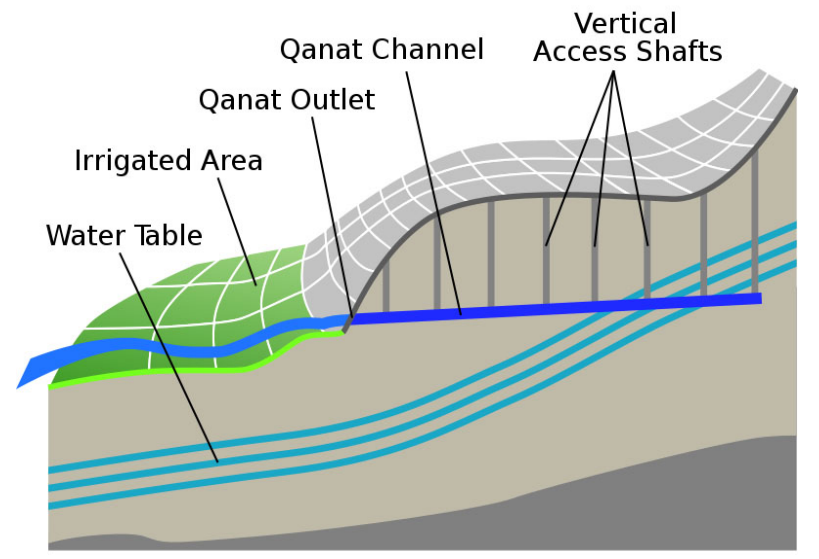

(Source:http://www.carolinemawer.com/whats-new/travel/see-inside-a-qan at/)

Figure 17. How a qanat works.

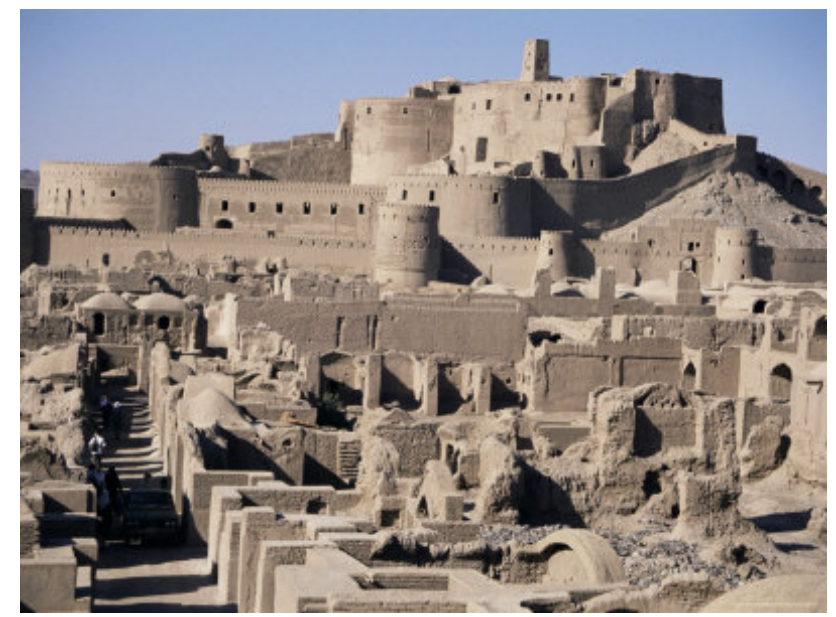

(Source:http://www.allposters.ch/-sp/Arg-E-Bam-the-Citade 1-Bam-Iran-Middle-East-Poster_i2659624_htm)

Figure 18. Arg-e Bam is the most representative example of a fortified medieval town built in vernacular technique using mud layers (Chineh).

\subsection{Ancient Township and Empire Remains}

The word township is used to refer to different kinds of settlements in different countries. An empire is a group of states or peoples under the control of a centralized ruling authority.

Vat Phou and Associated Ancient Settlements within the Champasak Cultural Landscape, witnessing the Laos' modernity revolving: "prosperity" in Khmer political expansiveness, "growth" during American political intrusion in year 60s and later the tourism policy called NayobaiChintanakan Mai (Whitington J. [20]).Vat Phou has a long history of constructing. It represents the origins of the Khmer civilization long before the appearance of Angkor (Figure 19). It was constructed in the 5th century; however, the ruins are dating back to the 9th and 12th centuries. Laos' modernity revolves around an experience of ambiguity. In Lao as in Thai, tan samai means 'of the age,' and implies more a sense of a fashionable changing contemporary rather than modernity as such. The subtlety of its ability to build close connections with Thailand and China, without simply being swamped by their vastly larger and more aggressive economy is a skilled politics of balance and ingenuity.

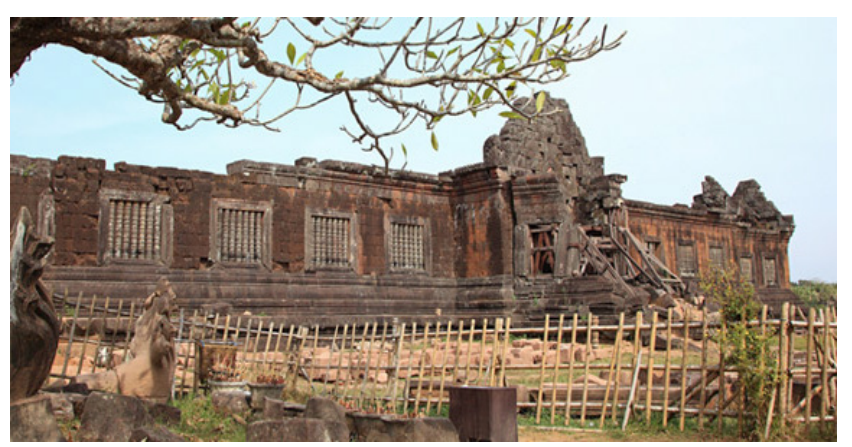

Figure 19. The Champasak Cultural preserves the heritage properties associated with the vast Khmer Empire from the 5th to the 15th centuries (Source: http://www.visit-mekong.com/laos/champasak/attractions.htm)

Underpinning the development within the Orkhon valley (Mongolia) for the past two millennia has been a strong culture of nomadic pastoralism (Figure 20). This culture is still a revered and is highly respected as a 'noble' way to live in harmony with the landscape. The Orkhon valley illustrates several significant stages in human history. First and foremost it was the centre of the Mongolian Empire; secondly it reflects a particular Mongolian variation of Turkish power; thirdly, the Tuvkhun hermitage monastery was the setting for the development of a Mongolian form of Buddhism; and fourthly, KharBalgas, reflects the Uighur urban culture in the capital of the Uighur Empire. Modern Mongolia comprises only about half of the vast Inner Asian region known throughout history as Mongolia. Even so, to appreciate this extensive scale of the cultural landscape, and to tap on the modern convenience, there is a typical heritage tourism tour being offered. 


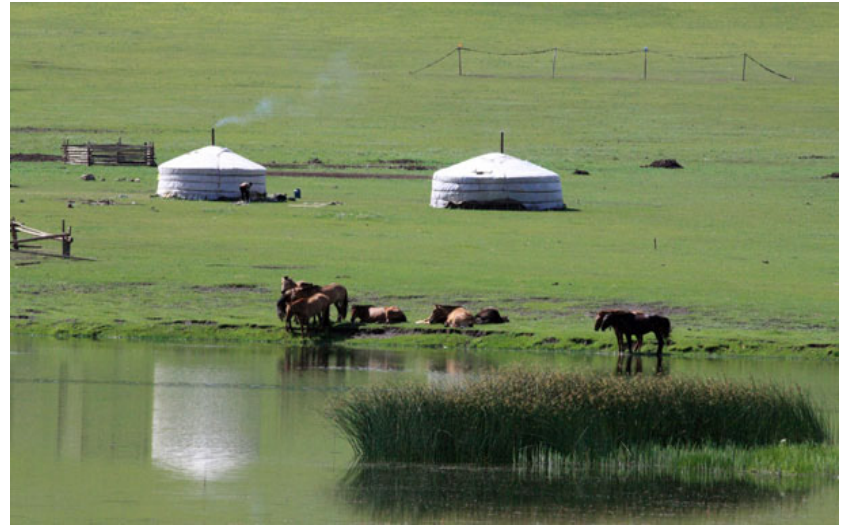

(Source:http://www.zendmentravel.com/tours/explore-central-mongolia-no mads-and-monasteries/)

Figure 20. Ride across undulating wooded hills and enrich one's riding experience in untouched wilderness, is one of the selling point for typical Orkhan Valley tour.

The Parthian Fortresses of Nisa in Turkmenistan (Figure 21) have been relatively undisturbed for nearly two millennia and conserve the unexcavated remains of an ancient civilization which skillfully combined its own traditional cultural elements with those of the Hellenistic and Roman west. The Parthian Empire was one of the most powerful and influential civilizations of the ancient world, and a brilliant rival of Rome which prevented the expansion of the Roman Empire to the east. Nisa, the capital of the Parthian Empire, is the outstanding symbol of the significance of this imperial power.

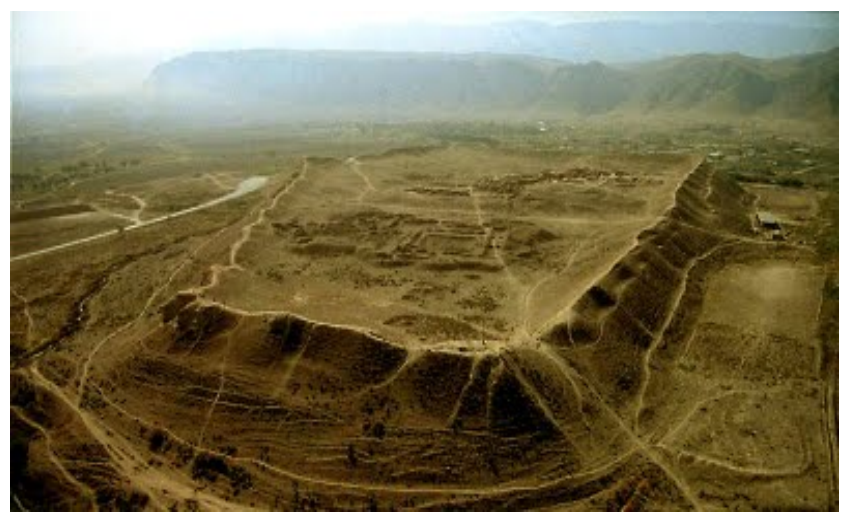

(Source:

http://unitedoneworld.blogspot.com/2009/10/october-27-republic-of-turkm enistan.html)

Figure 21. The Parthian Fortresses of Nisa consist of two tales of Old and New Nisa.

Today, Turkmenistan is unwilling to embrace the more unmanageable aspects of modernity like an open society. The most visible, and expensive, aspect of this tireless striving to some indefinable historical apotheosis has manifested itself in a gargantuan construction boom in the weird capital city, Ashgabat, and the utterly potty Caspian resort town of Awaza (Vlad [21]). The Turkmen population was made up of a number of tribes, all of which claimed descent from a single ancestor. The Turkmen shared this emphasis on genealogical descent, whose mobility and statelessness precluded forms of identity linked to the state. Under the right circumstances, this belief in a common ancestry had the potential to serve as a unifying factor (Edgar [22]).

\subsection{Intentional Human Intervention Landscape}

The improved landscape of West Lake (Hangzhou) can be seen to reflect Buddhist ideals imported into China from India such as 'Buddhist peacefulness' and 'nature as paintings', and in turn it had a major influence on landscape design in East Asia. Its causeways, islands, bridges, temples, pagodas and well defined views, were widely copied over China, and in Japan. Although its beauty has been celebrated by writers and artists since the Tang Dynasty (AD 618-907), Hangzhou's role as a centre of handicrafts and commerce was lost to the industrialized metropolis of Shanghai, only in the 1910s, Hangzhou sprang from the ashes as one of the most famous tourist destinations in China, and its role as a 'culture garden' continues to this day (Wang [23]).The visual integrity of the West Lake is well maintained towards the three hill sides, which seem to have been almost similar for the past 1,000 years (Figure 22). The view to the east is vulnerable to further expansion of Hangzhou city. However, considering the drastic urban changes of Hangzhou city over the past 10 years, from a regional town to a metropolis of eight million people, the property's visual integrity toward the city side is well managed. Faced with a modern regional arrangement that severely constrained the possibility for further development, Hangzhou discovered that what it had to rely upon was precisely its 'antiquity'.

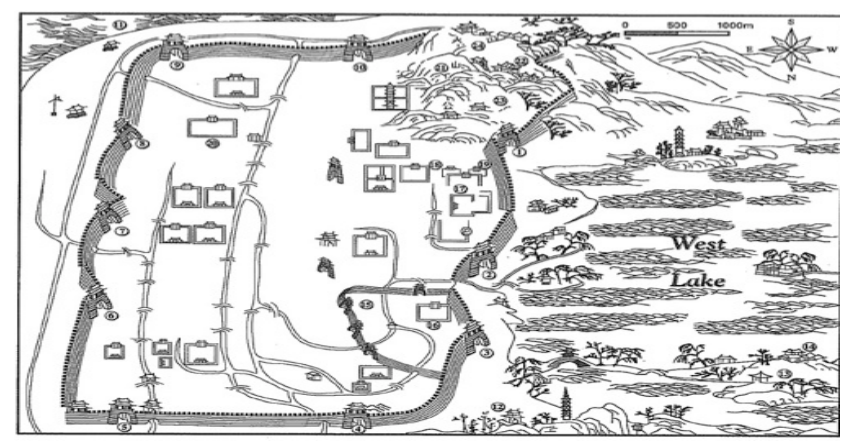

(Source:http://www.chinaheritagequarterly.org/features.php?searchterm $=02$ 8 tourism.inc\&issue $=028$ )

Figure 22. This Qing portrait of Hangzhou certainly does bear much resemblance to the contemporary image of the city that centers around West Lake.

\section{Discussions}

Under the category of Early Human Settlement and Spirituality (Grottos and Sacred Sites), at the very same site of Archaeological Landscape of Tamgaly, the action of Kazakh Muslims tying the rags at the bushes is synchronizing with the ancient action of petroglyphs, as the ritual dedication for this holy site pilgrimage. For Rock Shelter Bhimbetka, the current lifestyles of the India adivasi 
settlements still show the strong affinity, through the wall painting traditions. For Petroglyphic Complexes of the Mongolian Altai, the herders who have already been engaged in heritage protection in some soum, have reduced their seasonal migration as consequence that, livestock breeding and the seasonal migration of the nomad households are no longer organized by the government.

For Cultural Landscape and Archaeological Remains of the Bamiyan Valley, it showed us how the political reform during the Taliban in Afghanistan threatened the status of asset. For Mount Wutai, its revival also showed the social instability from the late Qing dynasty to the early years of the Republic of China, abrupt its' flourishing as an international pilgrimage centre. While Lushan National Park showcases its spiritual and political significance has endured to the present day, as well as its poetry and literary inspiration.

For Sacred Sites and Pilgrimage Routes in the Kii Mountain Range, the walking boom and wellness concerns create a new perception of the Kumano forest, which spoke of religious beliefs associating the forest as part of ascetic practice. For Sulaiman-Too Sacred Mountain, the huge Muslim world do recognize the city of Osh as one of the centers of Islam, despite the recent mobs that went on an arson and looting spree in Kyrgyzstan.

Under the category of Economy Activity Prove and Cultural (Plantation, Mining and Trade Route), Rice Terraces of the Philippine Cordilleras have to juggle between tradition and progress, looking at its erosion of architectural qualities by thoughtless replacement of the natural materials with simply rigid concrete, and roof thatch with galvanized iron sheets. For Iwami Ginzan Silver Mine and its Cultural Landscape, the outer town Omori still preserves the old townscape, which is a mixture of samurai and merchant houses, administrative buildings, temples, and shrines. Most of the time, the modernity and tradition in Israel manage to peacefully co-exist, so for Incense Route - Desert Cities in the Negev, it just needs a continuing comprehensive archaeological strategy for the whole ensemble. For Bam and Its Cultural Landscape, water system from the qanats defines both the social regions in the city and the layout of the city both in ancient time and present days.

Under the category of Ancient Township and Empire Remains, Vat Phou and Associated Ancient Settlements within the Champasak Cultural Landscape, witnessing the Laos' modernity revolving: "prosperity" in Khmer political expansiveness, "growth" during American political intrusion in year 60s and later the tourism policy called Nayobai Chintanakan Mai.For Orkhon Valley Cultural Landscape, it is one of the key areas in Mongolia where the links between nomadic pastoralism and the still highly respected as a 'noble' way to live in harmony with the landscape. For Parthian Fortresses of Nisa, as the capital of the Parthian Empire, it has the outstanding symbol of imperial significance. Under the right circumstances, the belief in a common ancestry had the potential to serve as a unifying factor among all Turkmen tribes.

Under the category of Intentional Human Intervention
Landscape, West Lake Cultural Landscape of Hangzhou still clearly conveys the idea of a 'lake with cultural meaning'. In keeping its selling point of "antiquity", it will be absolutely crucial that the skyline is maintained and ensure there is no encroachment.

\section{Conclusions}

Up to 2012, sixteen out of seventeen cultural landscapes in Asia justify the hypothesis that the cultural landscapes do contribute to ethnic or cultural identity affirmation and pride in Asia, in the probe of modernity. As we can see, each cultural landscape in Asia has its unique echo to its current context, except the less proven for Gobustan Rock Art Cultural Landscape in Azerbajian. Continuity, integrity, authenticity is one of the concerns for the cultural landscape listed, yet we shouldn't overlook the contemporary society value which superimpose the new perception and invention (e.g. Pilgrimage Routes in the Kii Mountain Range), as well as the political reform approach that could further enhance or threaten its status as world heritage, e.g. Bamiyan Valley and Sulaiman-Too. These examples remind us about the risk of change from situations which are very conducive or difficult to control.

The proven relationship between cultural landscape and Asian modernity brings out the significance in safeguarding the continuity of cultural landscape's essence amidst flow of modernity. To reemphasize, creating more and sustaining more cultural landscapes in Asia is certainly beneficial in a much wider scope. Further study may consider the urban upgrading, humanitarian improving, rehabilitation of heritage, sustainable urban conservation through specific political, administrative axis, as well as technical and executive axis, according to its region and country. This paper admitted its limitation on desktop research, however it serve as spearhead in its discourse. This will lead to more refined work simply because Asian modernity is certainly vast and heterogeneous as the variety of its cultural landscapes.

\section{REFERENCES}

[1] UNESCO, Operational Guidelines for the Implementation of the World Heritage Convention, UNESCO World Heritage Centre, Paris, pg. 84, 2005

[2] McDowell L., The transformation of cultural geography. In D. Gregory, R. Martin, and G. Smith, eds., Human Geography: Society, Space, and Social Science. Minneapolis: University of Minnesota Press, pg. 146-73, 1994

[3] Asian Modernity - Globalization Processes and Their Cultural and Political Localization, Documentation of a workshop of the Heinrich Böll Foundation, Berlin, 2004

[4] Wischermann, J., "Asian Modernity - Globalization Processes and Their Cultural and Political Localization", 
Documentation of a workshop of the Heinrich Böll Foundation, Berlin, 2004.

[5] Ten C.L., "Secularism and its Limits", in Michael S and Ten $\mathrm{C}$ eds. State and Secularism: Perspectives from Asia, World Scientific Publishing Co. Pte Ltd, Singapore, pg. 24, 2010

[6] Michael H.S.S., "The Secular State and its Challenge", in Michael S and Ten C eds. State and Secularism: Perspectives from Asia, World Scientific Publishing Co. Pted Ltd, Singapore, pg. 24, 2010

[7] UNESCO, World Heritage List, Online available from http://whc.unesco.org/en/list/1145 [Accessed: 21 May 2012], http://whc.unesco.org/en/list/1107[Accessed: 21 May 2012], http://whc.unesco.org/en/list/1334[Accessed: 21 May 2012].

[8] Lymer K., "Rags and rock art: the landscapes of holy site pilgrimage in the Republic of Kazakhstan", World Archaelogy 36:1, pg. 158-172, 2004

[9] Lkhagvadorj D., Hauck M., Dulamsuren C., and Tsogtbaata J., "Pastoral nomadism in the forest-steppe of the Mongolian Altai under a changing economy and a warming climate", Accepted for the Journal of Arid Environments, abstract., n.d.

[10] Advisory Body Evaluation 1996, Online available from http://whc.unesco.org/en/list/778

[11] Debreczeny K., "Wutai shan: Pilgrimage to five-Peak Mountain”, JIATS, no.6, THL, pg. 9-48, 2011

[12] ICOMOS "Evaluations of Cultural Properties", WHC-04/28COM/INF.14A, pg. 39, 2004, Online available from

http://whc.unesco.org/archive/2004/whc04-28com-inf14ae.p df [Accessed: 21 May 2012]

[13] Brown J., Mitchell N.J. \& Beresford M. (Eds.), The Protected Landscape Approach: Linking Nature, Culture and Community, IUCN, pg. 96, 2005

[14] Villaló, A., "World Heritage inscription and challenges to the survival of community life in Philippine cultural landscapes",
Online available from

http://data.iucn.org/dbtw-wpd/html/PA-protected-landscapeapproach/PartII-section7.html [Accessed: 21 May 2012]

[15] Japan Visitor, Online available from: http://www.japanvisitor.com/index.php?cID=460\&pID=268 0\#ixzz21VEvx4TQ

[16] Traphagan J. W. and Thompson C.S., "The Practice of Tradition and Modernity Contemporary Japan", State University of New York Press, Albany, pg.1-5, 2006

[17] World Heritage Memory Net, Online available from http://whmnet.org/collection/site.php?site $=1208$ [Accessed: 21 May 2012]

[18] Jokilehto J., Considerations on authenticity and integrity in world heritage context. City \& Time 2 (1), pg. 12-13, 2006

[19] Dezham Khoov M., Yazdi L. P., Archaeology and Contemporary Society, World Archaeology, 42 (3), abstract, 2010

[20] Whitington J., "Figureures of Lao Modernity", pg. 3-5, 2010, Online available from http://nus.academia.edu/ [Accessed: 21 May 2012]

[21] Vlad, "Turkmenistan Meets Oliver Twist: May I Have Some More Please?", dated Aug 14, 2010, Online available from http://ekspeditsya.wordpress.com/2010/08/14/turkmenistanmeets-oliver-twist-may-i-have-some-more-please/[Accessed: 21 May 2012]

[22] Edgar A. L., "Tribal Nation: The Making of Soviet Turkmenistan", Princeton University Press, 2004, Online available from http://press.princeton.edu/chapters/i7858.html [Accessed: 21 May 2012]

[23] Wang L.P., "Tourism and Spatial Change in Hangzhou, 1911-1927", China Heritage Quarterly, China Heritage Project, The Australian National University. 2011, Online available from http://www.chinaheritagequarterly.org/features.php?searchte $\mathrm{rm}=028$ tourism.inc\&issue $=028$ [Accessed: 21 May 2012] 